\title{
THE ROLE OF TECHNOLOGY ACCEPTANCE MODEL IN EXPLAINING EFFECT ON E-COMMERCE APPLICATION SYSTEM
}

\author{
Md Gapar Md Johar ${ }^{1}$ and Janatul Akmar Ahmad Awalluddin ${ }^{2}$ \\ ${ }^{1}$ Information Technology and Innovation Center, Management and Science University, \\ Selangor, Malaysia \\ gaparemsu. edu.my \\ ${ }^{2}$ Graduate School of Management, Management and Science University, Kuala Lumpur, \\ Malaysia \\ fainatul@yahoo.com
}

\begin{abstract}
Today e-commerce has become crucial element to transform some of the world countries into an information society. Business to consumer $(B 2 C)$ in the developing countries is not yet a normalcy as compared to the developed countries. Consumer behaviour research has shown disappointing results regarding the overall use of the Web for online shopping, despite its considerable promise as a channel for commerce. As the use of the Internet continues to grow in all aspects of daily life, there is an increasing need to better understand what trends of internet usage and to study the barriers and problem of ecommerce adoption. Hence, the purpose of this research is to define how far Technology Acceptance Model (TAM) contributed in e-commerce adoption. Data for this study was collected by the means of a survey conducted in Malaysia in 2010. A total of 611 questionnaire forms were delivered to respondents. The location of respondents was within Penang state. By studying this sample, conclusions would be drawn to generalize the interests of the population.
\end{abstract}

\section{KEYWORDS}

E-commerce, Technology Acceptances Model (TAM), e-commerce application, online shopping, online banking, online payment \& buying online.

\section{INTRODUCTION}

\subsection{Background}

Electronic Commerce or e-commerce has received much attention from governments, businesses and regional organizations or institutions. This importance has been attributed to a few converging factors. These factors include: first, the development of the use of the Internet as a means by which information is disseminated and through which communication and connectivity is enabled. Second, the affordability of personal computers had increased their computing capability, and the wide use of open standards in the computer software applications [6]. Third, is supportive legal policy where government and regulatory bodies are collaborating on a wider platform to ensure e-commerce law, policy and regulations are enforced for consumers' protection [12]. Lastly, broadband promoting where this year, government had announced 'Malaysia Broadband Initiative' to promote high speed broadband service and Malaysians will enjoy Internet surfing speeds from 5 megabits per second (Mbps) to 20Mbps [4]. 
International Journal of Managing Information Technology (IJMIT) Vol.3, No.3, August 2011

\subsection{E-Commerce in Malaysia}

Malaysia started accepting E-commerce facilities quite early along with other developed nations. The country adopted measures to develop computer-mediated environment for its retail business smoothly. As a result a parallel economy slowly developed side-by-side the standard or conventional retail. Retailers adopted E-commerce to strengthen their marketing strategies.

The government played an important role in ensuring the sustainability of E-commerce. They implemented infrastructure support by introducing broadband throughout the country. This year, the government had announced 'Malaysia Broadband Initiative' to promote high speed broadband service and Malaysians will enjoy Internet surfing speeds from 5 megabits per second (Mbps) to $20 \mathrm{Mbps}$ [4]. Besides, the government has allocated RM 1 billion to provide school children from poor households with Internet-enabled netbook computers, as part of the National Broadband Initiative. Under the programme, a student would only have to pay RM 38 a month for the netbook and Internet access. Needy students in rural areas will pay even less RM 20 a month. High speed broadband services are vital for the nation's economic growth, competitiveness, increasing investor confidence, and promoting innovative thinking. Furthermore, the Prime Minister also stated that RM 60 million would be invested to set up community broadband centres that would benefit 615,000 households in 246 locations in the country [4]. The second measure that was adopted was to ensure safe payment modalities.

A survey conducted by Zerogrey Ltd showed the acceptance of E-commerce is quite high in the country currently. Almost $38 \%$ of the respondents indicated their willingness to shop online in the near future. $20 \%$ of them already purchased online at least twice a month. But almost $42 \%$ indicated either their apprehension or lack of interest in using online payment methods. The responsibility of the government and the retailers now will be to turn this segment of potential users into online customers. Setting up safer payment methods can be the best approach. It is also the time to encourage M-commerce in the country [9].Standard A4 $(210 \mathrm{~mm}$ x $297 \mathrm{~mm})$ portrait page set-up should be used. The left, right, top and bottom margins should be $30 \mathrm{~mm}$. Do not use any headers, footers or footnotes. No page numbers. Single column. All main text paragraphs, including the abstract, must be fully (left and right) justified. All text, including title, authors, headings, captions and body, will be Times New Roman font.

\subsection{E-Commerce in ASEAN}

In addition, the ASEAN Telecommunications Ministers (TELMIN) met on 27-28 August 2002 and signed the Manila Declaration resolving to exploit ASEAN's competitive edge in the Information and Communications Technology (ICT) sector. Terms of references and work programmes have been developed for the five Telecommunications Senior Officials Meeting (TELSOM) working groups on information infrastructure, undertaking capacity building, universal access and digital divide in ASEAN, intra-ASEAN trade and investment in the telecommunications and IT sectors, and positive use of the Internet. The e-ASEAN Initiative has been transferred from the purview of the ASEAN Economic Ministers to the ASEAN Telecommunications and IT Ministers (TELMIN), except for elements relating to trade and investment liberalization and e-commerce promotion.

There is an e-ASEAN Working Group (EAWG), which continues to contribute to the implementation of the e-ASEAN Framework Agreement, covering the intra-ASEAN activities, cooperation with Dialogue Partners, and streamlining the current and future direction of EAWG functions. The EAWG has developed a funding mechanism to build sufficient financial resource with fast track approval process. The e-ASEAN operational mechanism has been restructured to reposition and enable the EAWG to respond to the need for convergence of information infrastructure and IT applications. 
International Journal of Managing Information Technology (IJMIT) Vol.3, No.3, August 2011

In addition, a Common Reference Framework for e-Commerce Legal Infrastructure has been published to assist the countries without, or with inadequate, e-commerce legislations. An ecommerce white paper to share available information on each country's initiatives and development is under preparation. A Cyber laws seminar was held in order to share best practices and learn from the experiences of the more developed countries in ASEAN. The e-ASEAN Public Key Infrastructure Forum has also been established. The studies on cross-border harmonization of e-transactions and signatures legal frameworks are underway [17].

\section{LITERATURE REVIEW}

\subsection{Perceived Characteristics of the Web}

Perceived characteristics of technology have been identified as a key variable to explain potential users' adoption intention and usage behaviour. Because different adopters might perceive attributes of a technology in different ways, their consequent behaviour related to the use of the technology might be different. Web site layout design and information content also are important in order to arouse initial consumers' interest to further explore a site [16]. Research in the ecommerce domain has shown that website features positively influence consumers' intention to engage in online activities [2]. The two major underlying models in the research context of the adoption of innovation and technology are the diffusion of innovations model and the technology acceptance model. A major focus in these studies has been how potential users' perceptions of the technology influence its adoption.

Using the diffusion of innovations model of Rogers, the work of Tornatzky and Klein, and other existing instruments based on Rogers' taxonomy, proposed an instrument to measure various perceptions of information technology adoption [14]. Another widely tested model in the context of information technology adoption is the technology acceptance model (TAM), which is based on the theory of reasoned action [13]. Significant empirical research has used TAM to predict user acceptance of information technology and to examine consumers' behaviour on the Web. It involves two constructs that model the adoption of IT. First, perceived usefulness is the degree to which an individual believes that using a particular system would enhance one's job performance. Second, perceived ease of use is the degree to which an individual believes that using a particular system would be free of physical and mental effort. A major focus in these studies has been on how potential users' perceptions of the technology influence its adoption.

\subsection{Problem and barrier of e-commerce in Malaysia}

Malaysian consumers are increasingly venturing online. Increasing urbanization and changing lifestyles of the urban Malaysians have contributed to this phenomenon. Malaysia is expected to lead growth in Internet in Asia [10].

Internet has created enormous change in the business environment. Systems are devised to facilitate Business-to-Business (B2B), Business-to-Customer (B2C), Business-to-Government (B2G), and Government-to-Citizen (G2C) and so on. Private communication networks and the internet are being increasingly used by organisations to establish corporate alliances with suppliers, business partners and customers.

Even though e-commerce is spreading worldwide, many customers are still reluctant to deal with it because of the security and privacy concerns [1]. While the internet helps make our lives richer and more convenient, it also provides a gateway to access our personal information. Many consumers feel that their personal information may be disclosed to others without their knowledge. Furthermore, viruses, hackers, crackers and worms have become the stuff of headlines with results that range from mere headache to a complete disaster. It is generally recognised that security measures are extremely important for e-commerce and all e businesses running on the internet. 
International Journal of Managing Information Technology (IJMIT) Vol.3, No.3, August 2011

As mentioned earlier, consumers' adoption of e-commerce is growing at a lower pace than expected. For example, the Small- and Medium-Sized Industries Association of Malaysia reported that in late 2005 less than $5 \%$ of its members were involved in B2C business. Furthermore, according to mid-2005 survey conducted by the Malaysian Communications Multimedia Commission (MCMC), only 9.3\% of internet users had purchased products or services through the internet during the preceding three months [1].

The primary reasons cited for this are: lack of security and privacy of consumers' personal data including credit card number, identity theft, virus, break-in attacks, denial-of-service, etc. An identity thief steals key pieces of personal information and uses it to impersonate someone and commits crimes in his/her name and it is regarded as the fastest growing internet crime today. The ability to know the identity of the person or the business enterprise with whom doing business is important. Thus, authentication services are fundamental to achieving secured e-commerce. There are 17 currently available authentication mechanisms in e-commerce using six criteria, namely, robustness, acceptance, and cost, ease of use, portability, security and there are needs for usercentric global identity management in e- commerce.

In the earlier days of the internet, people were obsessed with the notion that hackers could capture credit card numbers while these are transmitted through the internet. As a result, merchants paid more attention on protecting credit card data by ensuring that it was not transmitted in its original form, by encrypting it so that it could travel securely over the internet. However, in reality, most security breaches occur after the transaction is completed. It means when a customer's credit card number is kept unprotected in merchant's computer, the possibility of misuse is more. In this way, a hacker can net a file of several thousand credit card numbers. Therefore, protecting merchant's website is more important than securing the transactions through website at the time of the transaction.

\section{METHODOLOGY}

\subsection{Variables}

The two types of variables available in this research were dependent variables and independent variables. It was crucial to identify these two types of variables in order to develop a solid conceptual framework. The dependent variables were the variables of primary interest for the research. The goal of this research was to understand and describe the dependant variables, or to explain its variability, or predict it. In the case of this research, the primary dependant variable would be consumers' intention to use the e-commerce system.

Independent variables significantly influenced the dependant variables in either positive or negative ways. The variances in the dependent variables were accounted for by the independent variables. The independent variables involved in this research were perceived usefulness, perceived ease of use and perceived enjoyment and consumer trait. These four independent variables would be tested to identify whether or not these variables possess influence on the dependent variable.

\subsection{Conceptual Framework}

The conceptual framework was the foundation on which the entire research project was based. It was logically developed, described and elaborated network of associations among the variables deemed relevant to the research [15].

The objectives of this study are to find the factors that influencing and contributing to the customers' intention to use e-commerce system. For developing an in-depth understanding of consumers' attitudes toward online shopping and their intentions to shop on the Internet, the researcher built up a framework, based on previous research on consumer adoption of new 
technologies and services. As noted earlier, in this framework e-commerce is defined as the use of online stores by consumers up until the transactional stage of purchasing and logistics.

The core constructs of this framework are adapted from the Technology Acceptance Model (TAM), an influential research model in the information systems field. Although this model is specifically tailored to understand the adoption of computer-based technologies on the job or in the workplace, it has proven to be suitable as a theoretical foundation for the adoption of ecommerce as well. Therefore, the TAM constructs are used as a basis for this research framework.

The schematic diagram in figure 1 clearly explained the relationships among the variables. Once these relationships were identified the hypotheses can be postulated easily and the dynamics of the situation was clearly comprehensible. The model consists of four factors that were positioned to have an effect adoption of e-commerce.

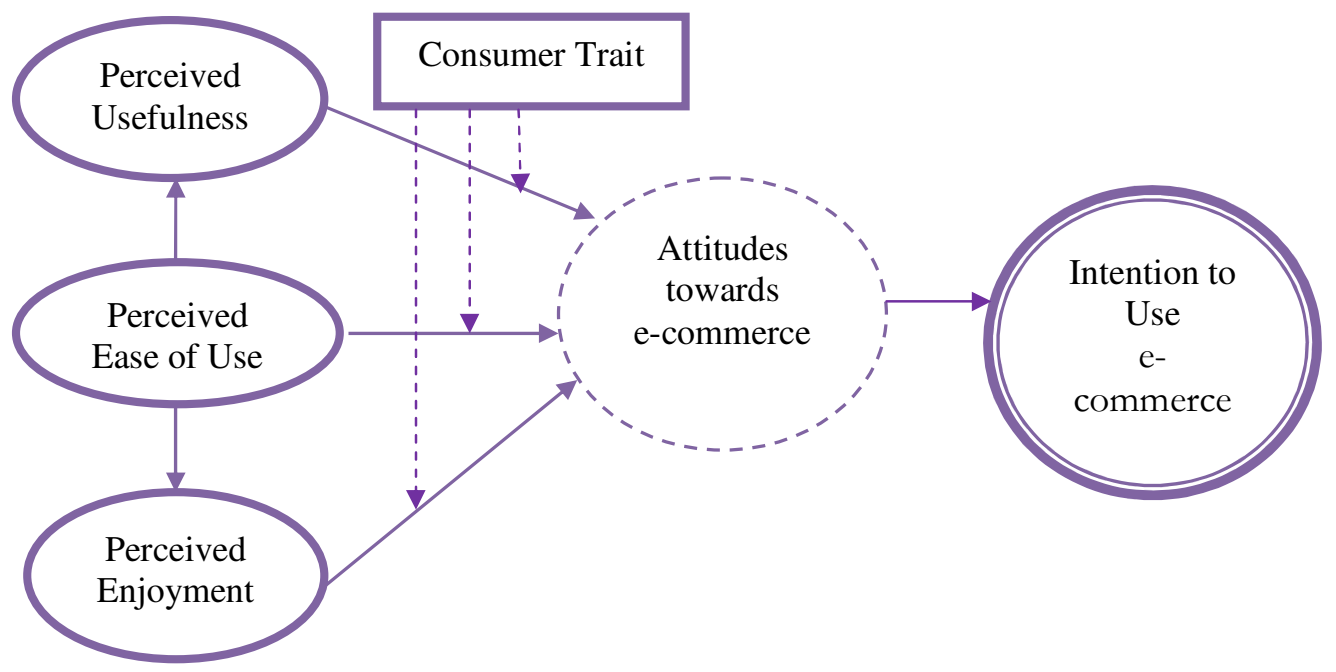

Figure 1. The research model

\subsection{Research hypotheses}

\subsubsection{Perceived usefulness}

Perceived usefulness is defined here as the degree to which a person believes that using a particular system would enhance his or her job performance. On the basis of these findings, the following hypothesis is proposed:

$\mathrm{H}_{1} \quad$ There was a positive relationship between perceived usefulness and consumer intention in using e-commerce.

\subsubsection{Perceived ease of use}

Ease of use is defined as the individual's perception that using the new technology will be free of hardship and hard effort. Applying this to the research context, ease of use is the consumer's perception that shopping on the Internet will involve only minimum effort. By applying these into e-commerce context we hypothesize:

$\mathrm{H}_{2} \quad$ There was a positive relationship between perceived ease of use and consumer intention in using e-commerce. 
International Journal of Managing Information Technology (IJMIT) Vol.3, No.3, August 2011

\subsubsection{Perceived enjoyment}

Perceived enjoyment refers to the extent to which the activity of using a computer is perceived enjoyable in its own right. Perceived enjoyment significantly affects intentions to use electronic system [3].

$\mathrm{H}_{3} \quad$ There was a positive relationship between perceived enjoyment and consumer intention in using e-commerce.

\subsubsection{Consumer trait}

Consumer traits that are of interest in understanding why consumers shop on the Internet include demographic factors and personality characteristics [12].

$\mathrm{H}_{4} \quad$ There was a positive relationship between the age group and consumer intention in using e-commerce

$\mathrm{H}_{5} \quad$ There was a positive relationship between level of education and consumer intention in using e-commerce

$\mathrm{H}_{6} \quad$ There was a positive relationship between level of income and consumer intention in using e-commerce

\section{DATA ANALYSIS}

\subsection{Hypotheses Testing}

\subsubsection{E-commerce Adoption and Age Group Analysis}

The alternative hypothesis $\mathrm{H}_{4}$ is that there was a positive relationship between the age group and the adoption of e-commerce or the null hypothesis is that there was no association between the factor of e-commerce adoption and age group.

Table 1 shows, the null hypothesis were rejected establishing the fact that there was an interrelationship between the age group and e-commerce adoption. It was shown that the age group between $51-60(90.0 \%)$ had higher tendency to adopt e-commerce.

Table 1. E-commerce adoption and Age Group Crosstabulation

\begin{tabular}{|c|c|c|c|c|c|}
\hline & & & \multicolumn{2}{|c|}{ EC_adoption } & \multirow[b]{2}{*}{ Total } \\
\hline & & & yes & no & \\
\hline \multirow[t]{9}{*}{ Age } & $20-30$ & Count & 272 & 115 & 387 \\
\hline & & Expected Count & 296.4 & 90.6 & 387.0 \\
\hline & & $\%$ within Age & $70.3 \%$ & $29.7 \%$ & $100.0 \%$ \\
\hline & $31-40$ & Count & 115 & 17 & 132 \\
\hline & & Expected Count & 101.1 & 30.9 & 132.0 \\
\hline & & $\%$ within Age & $87.1 \%$ & $12.9 \%$ & $100.0 \%$ \\
\hline & $41-50$ & Count & 27 & 5 & 32 \\
\hline & & Expected Count & 24.5 & 7.5 & 32.0 \\
\hline & & $\%$ within Age & $84.4 \%$ & $15.6 \%$ & $100.0 \%$ \\
\hline
\end{tabular}


International Journal of Managing Information Technology (IJMIT) Vol.3, No.3, August 2011

\begin{tabular}{|c|c|c|c|c|}
\hline $51-60$ & Count & 54 & 6 & 60 \\
\hline & Expected Count & 46.0 & 14.0 & 60.0 \\
\hline & $\%$ within Age & $90.0 \%$ & $10.0 \%$ & $100.0 \%$ \\
\hline Total & Count & 468 & 143 & 611 \\
\hline & Expected Count & 468.0 & 143.0 & 611.0 \\
\hline & $\%$ within Age & $76.6 \%$ & $23.4 \%$ & $100.0 \%$ \\
\hline
\end{tabular}

Table 2 shows, the chi-square value is 23.851 and the degree of freedom is 3 . The p-value of the test is less than 0.001 . The minimum expected count is 7.49 , which is more than 1 . Thus, it can be concluded that e-commerce adoption depends on age.

Table 2. E-commerce adoption and Age Group Chi-Square Tests

\begin{tabular}{|c|c|c|c|}
\hline \multicolumn{4}{|c|}{ Chi-Square Tests } \\
\hline & Value & df & $\begin{array}{l}\text { Asymp. Sig. (2- } \\
\text { sided) }\end{array}$ \\
\hline Pearson Chi-Square & $23.851^{\mathrm{a}}$ & 3 & .000 \\
\hline Likelihood Ratio & 25.835 & 3 & .000 \\
\hline $\begin{array}{l}\text { Linear-by-Linear } \\
\text { Association }\end{array}$ & 18.110 & 1 & .000 \\
\hline $\mathrm{N}$ of Valid Cases & 611 & & \\
\hline
\end{tabular}

a. 0 cells $(.0 \%)$ have expected count less than 5 . The minimum expected count is 7.49 .

\subsubsection{E-commerce Adoption and Education Level Analysis}

The alternative hypothesis $\mathrm{H}_{5}$ is that there was a positive relationship between the education level and the adoption of e-commerce or the null hypothesis is that there was no association between the factor of e-commerce adoption and education level.

A table 3 show, the null hypothesis was rejected establishing the fact that there was an interrelationship between the education level and e-commerce adoption. Even though the numbers of PHD's respondents were very low compared to others, but in this case, it is acceptable since the amount of expected count is more than 1 . Therefore, in this case, it is unnecessary to merge PHD holders with master holders because it has already fulfilled the expected count requirement. Lastly, this analysis showed that those who adopted e-commerce are those with higher education level.

Table 3. E-commerce Adoption and Education Level Crosstabulation Education * EC_adoption Crosstabulation

\begin{tabular}{|ll|r|r|r|}
\hline & & \multicolumn{2}{|c|}{ EC_adoption } & \multicolumn{1}{|c|}{ Total } \\
\cline { 3 - 4 } & & \multicolumn{1}{c|}{ yes } & \multicolumn{1}{c|}{ no } & \multicolumn{1}{c|}{ Totan } \\
\hline Education phd & Count & 7 & 0 & 7.0 \\
& & 5.4 & 1.6 & 7.0 \\
& Expected Count & $.0 \%$ & $100.0 \%$ \\
\hline
\end{tabular}


International Journal of Managing Information Technology (IJMIT) Vol.3, No.3, August 2011

\begin{tabular}{|ll|r|r|r|}
\hline master & Count & 187 & 8 & 195 \\
& Expected Count & 149.4 & 45.6 & 195.0 \\
& \% within Education & $95.9 \%$ & $4.1 \%$ & $100.0 \%$ \\
\hline bachelor & Count & 184 & 22 & 206 \\
& Expected Count & 157.8 & 48.2 & 206.0 \\
& \% within Education & $89.3 \%$ & $10.7 \%$ & $100.0 \%$ \\
\hline & Count & 90 & 113 & 203 \\
& diploma & 155.5 & 47.5 & 203.0 \\
& & $44.3 \%$ & $55.7 \%$ & $100.0 \%$ \\
\hline & Expected Count & 468 & 143 & 611 \\
& \% within Education & 468.0 & 143.0 & 611.0 \\
& Count & $76.6 \%$ & $23.4 \%$ & $100.0 \%$ \\
\hline
\end{tabular}

Table 4 shows, the chi-square value is 179.125 and the degree of freedom is 3 . The p-value of the test is less than 0.001 . The minimum expected count is 1.64 , which is more than 1 . Thus, it can be concluded that e-commerce adoption depends on education.

Table 4. E-commerce adoption and Education Level Chi-Square Tests

\begin{tabular}{|c|c|c|c|}
\hline & Value & df & $\begin{array}{c}\text { Asymp. Sig. (2- } \\
\text { sided) }\end{array}$ \\
\hline Pearson Chi-Square & $179.125^{\mathrm{a}}$ & 3 & .000 \\
\hline Likelihood Ratio & 179.355 & 3 & .000 \\
\hline $\begin{array}{l}\text { Linear-by-Linear } \\
\text { Association }\end{array}$ & 148.033 & 1 & .000 \\
\hline $\mathrm{N}$ of Valid Cases & 611 & & \\
\hline
\end{tabular}

a. 1 cells $(12.5 \%)$ have expected count less than 5 . The minimum expected count is 1.64 .

\subsubsection{E-commerce Adoption and Annual Income Level Analysis}

The alternative hypothesis $\mathrm{H}_{6}$ is that there was a positive relationship between the annual income level and the adoption of e-commerce or the null hypothesis is that there was no association between the factor of e-commerce adoption and annual income level.

Table 5 shows, the null hypothesis were rejected establishing the fact that there was an interrelationship between the annual income level and e-commerce adoption. It was shown that those earning higher wages had higher tendency to adopt e-commerce. 
International Journal of Managing Information Technology (IJMIT) Vol.3, No.3, August 2011

Table 5. E-commerce Adoption and Annual Income Level Crosstabulation Income * EC_adoption Crosstabulation

\begin{tabular}{|c|c|c|c|c|c|}
\hline & & & EC_ad & tion & \\
\hline & & & yes & no & Total \\
\hline Incom & below RM 20,000 & Count & 84 & 108 & 192 \\
\hline & & Expected Count & 147.1 & 44.9 & 192.0 \\
\hline & & $\%$ within Income & $43.8 \%$ & $56.3 \%$ & $100.0 \%$ \\
\hline & RM 20,001 - RM 30,000 & Count & 102 & 17 & 119 \\
\hline & & Expected Count & 91.1 & 27.9 & 119.0 \\
\hline & & $\%$ within Income & $85.7 \%$ & $14.3 \%$ & $100.0 \%$ \\
\hline & RM 30,001 - RM 40,000 & Count & 102 & 11 & 113 \\
\hline & & Expected Count & 86.6 & 26.4 & 113.0 \\
\hline & & $\%$ within Income & $90.3 \%$ & $9.7 \%$ & $100.0 \%$ \\
\hline & RM 40,001 - RM 50,000 & Count & 44 & 3 & 47 \\
\hline & & Expected Count & 36.0 & 11.0 & 47.0 \\
\hline & & $\%$ within Income & $93.6 \%$ & $6.4 \%$ & $100.0 \%$ \\
\hline & RM 50,001 - RM 60,000 & Count & 27 & 2 & 29 \\
\hline & & Expected Count & 22.2 & 6.8 & 29.0 \\
\hline & & $\%$ within Income & $93.1 \%$ & $6.9 \%$ & $100.0 \%$ \\
\hline & above RM 60,000 & Count & 109 & 2 & 111 \\
\hline & & Expected Count & 85.0 & 26.0 & 111.0 \\
\hline & & $\%$ within Income & $98.2 \%$ & $1.8 \%$ & $100.0 \%$ \\
\hline Total & & Count & 468 & 143 & 611 \\
\hline & & Expected Count & 468.0 & 143.0 & 611.0 \\
\hline & & $\%$ within Income & $76.6 \%$ & $23.4 \%$ & $100.0 \%$ \\
\hline
\end{tabular}

Table 6 shows, the chi-square value is 173.745 and the degree of freedom is 5 . The p-value of the test is less than 0.001 . The minimum expected count is 6.79 , which is more than 1 . Thus, it can be concluded that e-commerce adoption depends on income.

Table 6. E-commerce adoption and Annual Income Level Chi-Square Tests

Chi-Square Tests

\begin{tabular}{|c|c|c|c|}
\hline & Value & $\mathrm{df}$ & $\begin{array}{l}\text { Asymp. Sig. (2- } \\
\text { sided) }\end{array}$ \\
\hline Pearson Chi-Square & $173.745^{\mathrm{a}}$ & 5 & .000 \\
\hline Likelihood Ratio & 175.101 & 5 & .000 \\
\hline $\begin{array}{l}\text { Linear-by-Linear } \\
\text { Association }\end{array}$ & 114.372 & 1 & .000 \\
\hline $\mathrm{N}$ of Valid Cases & 611 & & \\
\hline
\end{tabular}


Chi-Square Tests

\begin{tabular}{|c|c|c|c|}
\hline & Value & $\mathrm{df}$ & $\begin{array}{c}\text { Asymp. Sig. (2- } \\
\text { sided) }\end{array}$ \\
\hline Pearson Chi-Square & $173.745^{\mathrm{a}}$ & 5 & .000 \\
\hline Likelihood Ratio & 175.101 & 5 & .000 \\
\hline $\begin{array}{l}\text { Linear-by-Linear } \\
\text { Association }\end{array}$ & 114.372 & 1 & .000 \\
\hline $\mathrm{N}$ of Valid Cases & 611 & & \\
\hline
\end{tabular}

a. 0 cells $(.0 \%)$ have expected count less than 5 . The minimum expected count is 6.79 .

\subsection{Multiple Regressions}

\subsubsection{Factor Analysis}

Table 7 shows the factors analysis for variables perceived usefulness, perceived ease of use and perceived enjoyment.

Table 7: The Factor Analysis

\begin{tabular}{|c|c|c|c|}
\hline & \multicolumn{3}{|c|}{ Factors } \\
\hline Variables & $\begin{array}{l}\text { Perceived } \\
\text { Usefulness }\end{array}$ & $\begin{array}{l}\text { Perceived } \\
\text { Ease of Use }\end{array}$ & $\begin{array}{c}\text { Perceived } \\
\text { Enjoyment }\end{array}$ \\
\hline $\begin{array}{l}\text { E-commerce enables me to save more } \\
\text { time }\end{array}$ & 0.862 & & \\
\hline E-commerce is convenient & 0.862 & & \\
\hline $\begin{array}{l}\text { E-commerce enables me to purchase } \\
\text { any item more quickly }\end{array}$ & 0.862 & & \\
\hline $\begin{array}{l}\text { E-commerce would improved my } \\
\text { performance in making online shopping }\end{array}$ & 0.862 & & \\
\hline Learning to use e-commerce is easy & & 0.899 & \\
\hline E-commerce is easy to use & & 0.899 & \\
\hline $\begin{array}{l}\text { E-commerce provides understandable } \\
\text { interface }\end{array}$ & & 0.891 & \\
\hline $\begin{array}{l}\text { It is easy to become skilful at using the } \\
\text { e-commerce system }\end{array}$ & & 0.891 & \\
\hline E-commerce is flexible & & 0.849 & \\
\hline Fun & & & 0.874 \\
\hline Pleasant & & & 0.867 \\
\hline Positive & & & 0.865 \\
\hline Exciting & & & 0.874 \\
\hline Wise & & & 0.87 \\
\hline
\end{tabular}

ENTER method regression analyses were conducted to ascertain the best set of consumer acceptance on e-commerce. To identify the predictors of consumer acceptance, 3- predictors multiple linear regression models was proposed. The 3-predictors variables were perceived 
usefulness $\left(\mathrm{X}_{1}\right)$, perceived ease of use $\left(\mathrm{X}_{2}\right)$ and perceived enjoyment $\left(\mathrm{X}_{3}\right)$. The equation of the proposed multiple linear regression models was as follows (Equation 1):

$\mathrm{Y}_{1}=\mathrm{b}_{\mathrm{o}}+\mathrm{b}_{1} \mathrm{X}_{1}+\mathrm{b}_{2} \mathrm{X}_{2}+\mathrm{b}_{3} \mathrm{X}_{3}+e$

Where:

$\mathrm{Y}_{1}$ : Consumer acceptance on e-commerce

$\mathrm{b}_{\mathrm{o}}$ : Intercept

$\mathrm{b}_{1-3}$ : Slopes (estimates of coefficients)

$\mathrm{X}_{1}$ : Perceived usefulness

$\mathrm{X}_{2}$ : Perceived ease of use

$\mathrm{X}_{3}$ : Perceived enjoyment

$e:$ Random error

As depicted in table 8, the estimate of the augmented model (Equation 2) coefficients for $b_{0}$ was $0.755, b_{1}$ was $0.309, b_{2}$ was 0.272 and $b_{3}$ was 0.257 . Therefore, the final estimated model was shown in Equation 2.

Table 8. Estimates of Coefficients for Consumer Acceptance ( $\left.\mathrm{Y}_{1}\right)$ Model

Coefficients $^{\mathrm{a}}$

\begin{tabular}{|c|c|c|c|c|c|c|}
\hline \multirow{2}{*}{\multicolumn{2}{|c|}{ Model }} & \multicolumn{2}{|c|}{$\begin{array}{c}\text { Unstandardized } \\
\text { Coefficients } \\
\end{array}$} & \multirow{2}{*}{$\begin{array}{c}\text { Standardized } \\
\text { Coefficients } \\
\\
\text { Beta } \\
\end{array}$} & \multirow[b]{2}{*}{$\mathrm{t}$} & \multirow[b]{2}{*}{ Sig. } \\
\hline & & B & $\begin{array}{l}\text { Std. } \\
\text { Error }\end{array}$ & & & \\
\hline \multirow[t]{4}{*}{1} & (Constant) & .755 & .135 & & 5.596 & .000 \\
\hline & Perceived_Usefulness & .309 & .047 & .275 & 6.609 & .000 \\
\hline & Perceived_Ease_of_Use & .272 & .053 & .274 & 5.117 & .000 \\
\hline & Perceived_Enjoyment & .257 & .040 & .287 & 6.470 & .000 \\
\hline
\end{tabular}

a. Dependent Variable: Intention_to_Use

$\mathrm{Y}_{1}=0.755+0.309 \mathrm{X}_{1}+0.272 \mathrm{X}_{2}+0.257 \mathrm{X}_{3}+e$

(Equation 2)

Where:

$\mathrm{Y}_{1}$ : Consumer acceptance on e-commerce

$\mathrm{X}_{1}$ : Perceived Usefulness

$\mathrm{X}_{2}$ : Perceived Ease of Use

$\mathrm{X}_{3}$ : Perceived Enjoyment

$e:$ Random error

Based on explanatory variables and their coefficients all variables which perceived usefulness $(\mathrm{t}=$ $6.609, \mathrm{p}<0.01)$, perceived ease of use $(\mathrm{t}=5.117, \mathrm{p}<0.01)$ and perceived enjoyment $(\mathrm{t}=6.470, \mathrm{p}$ $<0.01)$ are statistically significant. The overall model was statistically significant $(\mathrm{R} 2=0.577, \mathrm{p}$ $<0.01)$. The results of the regression analysis were presented in table 9. The R-squared value of 
International Journal of Managing Information Technology (IJMIT) Vol.3, No.3, August 2011

0.577 implied that the 3-predictor variables explained about $57.7 \%$ of the variance in consumer acceptance.

Table 9. Model Summary for Consumer Acceptance $\left(\mathrm{Y}_{1}\right)$ Model

\begin{tabular}{|c|c|c|c|c|c|c|c|c|c|c|}
\hline \multicolumn{11}{|c|}{ Model Summary ${ }^{\mathrm{b}}$} \\
\hline \multirow[b]{2}{*}{ Model } & \multirow[b]{2}{*}{$\mathrm{R}$} & \multirow[b]{2}{*}{$\begin{array}{c}\mathrm{R} \\
\text { Square }\end{array}$} & \multirow[b]{2}{*}{$\begin{array}{l}\text { Adjusted } \\
\text { R Square }\end{array}$} & \multirow[b]{2}{*}{$\begin{array}{c}\text { Std. Error } \\
\text { of the } \\
\text { Estimate }\end{array}$} & \multicolumn{5}{|c|}{ Change Statistics } & \multirow[b]{2}{*}{$\begin{array}{l}\text { Durbin- } \\
\text { Watson }\end{array}$} \\
\hline & & & & & $\begin{array}{c}\mathrm{R} \\
\text { Square } \\
\text { Change }\end{array}$ & $\begin{array}{c}\mathrm{F} \\
\text { Change }\end{array}$ & df1 & df2 & $\begin{array}{c}\text { Sig. F } \\
\text { Change }\end{array}$ & \\
\hline 1 & $.760^{2}$ & .577 & .575 & .41360 & .577 & 276.023 & 3 & 607 & .000 & .832 \\
\hline
\end{tabular}

a. Predictors: (Constant), Perceived_Enjoyment, Perceived_Usefulness, Perceived_Ease_of_Use

b. Dependent Variable: Intention_to_Use

\section{CONCLUSION}

\subsection{Introduction}

The primary objective of this study was to find the factors that influencing and contributing to the customers' intention to use e-commerce. TAM has proven to be a useful theoretical model in helping to understand and explain use behaviour in IS implementation. It has been tested in many empirical researches and the tools used with the model have proven to be of quality and to yield statistically reliable results [8].

The present study was the first attempt to examine TAM in relation to virtual model technology offered by an online apparel retailer [7]. The findings of the present study indicate that TAM offers valuable constructs (perceived usefulness, perceived ease of use, and perceived enjoyment) to explain the effect of e-commerce adoption.

The framework that was proposed in this article offers a potentially useful starting point for the development of improved insight into this aspect of e-commerce adoption issues. In this research, emphasize factors that contributed to the e-commerce acceptances and demographics segments that will contributed to the e-commerce acceptances as well.

\subsection{Recommendation}

Strategic efforts of retaining online customers were determined by the user's level of sophistication. These efforts were undermined by the competitive forces within the e-commerce environment where there was a reduction in consumers' search cost, lower barriers to entry, and reduced distinctiveness of firms. Effective retention of online users let the web site grow leading to monetary benefits for businesses due to loyal customers would likely to do further purchases and have positive words of mouth and were also willing to pay more for the same services.

E-commerce body, agencies and web providers should advertise and publicize their security innovations, as this would play a role in improving consumer confidence in their service. The three golden rules for e-commerce body and web providers were communication, campaign and reliability. If customers were aware of what was on offer, they would soon want to try it. 
International Journal of Managing Information Technology (IJMIT) Vol.3, No.3, August 2011

\subsection{Future Research}

The discussed findings and their implications were obtained from one single study that examined a particular technology and targeted a specific user in Malaysia. Thus, this study needs to exercise caution when generalizing the findings and discussion to other technologies or groups.

These limitations pave the way to future studies. First, future research can use different methodologies, such as longitudinal studies, focus groups and interviews to examine the relationship between trends, barriers and customer purchase behaviour in online application contexts.

Second, the growth of the internet and online application system will continue, and future research can replicate similar studies solely involving e-commerce, measuring actual purchase behaviours instead of intentions.

\section{REFERENCES}

[1] Ahmed, M., Hussein, R., Minakhatun, R. and Islam R., (2007) "Building consumers' confidence in adopting e-commerce: A Malaysian case", International Journal Business \& Systems Research, Vol. 1, No. 2, pp236-255.

[2] Alhudaithy, A.I. and Kitchen, P.J., (2009) "Rethinking models of technology adoption for Internet banking: The role of website features", Journal of Financial Services Marketing, Vol. 14, No. 1, pp56-69.

[3] Amin, H., (2009) "An analysis of online banking usage intentions: An extension of technology acceptance model”, International Journal Business and Society, Vol. 10, No. 1, pp27-40.

[4] Habibu, S. and Ho, S. "RM1bil initiative to promote high-speed broadband usage" [Online] Available at http://thestar.com.my/news/story.asp?file=/2010/3/25/nation/5931577\&sec=nation. Accessed on November 5th 2010.

[5] Internet World Stats. "Internet usage in ASEAN" [Online] Available at http://www.internetworldstats.com/stats3.htm. Accessed on November 5th 2010

[6] Kaur. K., (2005) "Consumer protection in e-commerce in Malaysia: An overview”, Journal of the UNE Asia Centre, No., pp1-14.

[7] Lee, H.H., Fiore, A.M. and Kim, J., (2006) "The role of the technology acceptance model in explaining effects of image interactivity technology on consumer responses" International Journal of Retail \& Distribution Management, Vol. 34, No. 8, pp 621-644.

[8] Legris, P., Ingham, J. and Collerette, P., (2003) "Why do people use information technology? A critical review of the technology acceptance model" Journal of Information \& Management, No. 40, pp191-204.

[9] "Malaysia : E-commerce Success Story" [Online] Available at http://www.zerogrey.com/index.php/eshop/info/on/Zerogrey-Malaysia:-Ecommerce-SuccessStory.html/cId/359/. Accessed on November 5th 2010

[10] “Malaysia's E-Commerce Statistics” from http://malaysiacrunch.blogspot.com/2009/09/malaysias-ecommerce-statistics.html. Accessed on November 5th 2010

[11] Mirandah, G. "Internet law - The future of e-commerce in Malaysia" [Online] Available at http://www.ibls.com/internet_law_news_portal_view.aspx?s=latestnews\&id=1917. Accessed on November 5th 2010

[12] Monsuwe, T.P., Dellaert, B.G.C. and Ruyter, K.D., (2004) "What drives consumers to shop online? A literature review”, International Journal of Service Industry Management, Vol. 15, No. 1, pp102-121.

[13] Nicoles, C.L., Castillo, F.J.M. and Bouwman, H. , (2008) "An assessment of advanced mobile services acceptance: Contributions from TAM and diffusion theory models", Information \& Management, No. 45, pp359-364. 
International Journal of Managing Information Technology (IJMIT) Vol.3, No.3, August 2011

[14] Rogers, E., (1995) “Diffusion of Innovation”, fourth ed., New York: Free Press.

[15] Sekaran, U. and Bougie, R., (2010) "Theoretical framework In theoretical framework and hypothesis development”. Research Methods for Business: A Skill Building Approach, United Kingdom: Wiley, pp. 80

[16] So, W.C.M., Wong, T.N.D and Sculli, D., (2005) "Factors affecting intentions to purchase via the internet”, Journal of Industrial Management \& Data Systems, Vol. 105, No. 9, pp1225-1244.

[17] “Telecommunications and IT” from http://www.aseansec.org/7808.htm. Accessed on November 5th 2010

\section{Authors}

Prof. Dr. Md Gapar Md Johar, PhD, MSc, BSc (Hons) is a certified e-commerce consultant; he has over 30 years working experience in software and application development and has developed many applications such as Housing Loan Accounting System, Commercial Vehicle Licensing System, Human Resource Management System, Learning Content Management System, Campus Management System, Student Relationship Management System and Hospital Information System. His research interests include object-oriented analysis and design, software engineering, Java programming, digital image analysis, Radio Frequency Identification (RFID) and knowledge management. Currently he is involved in research and development of Jawi Word Processor and Converter in open system environment, RFID application, image processing and character recognition, computer forensic and security, e-learning and digital content design.

Janatul Akmar Ahmad Awalluddin is a postgraduate student at Management \& Science University and currently she is a part-time lecturer for UITM, Penang, Malaysia.
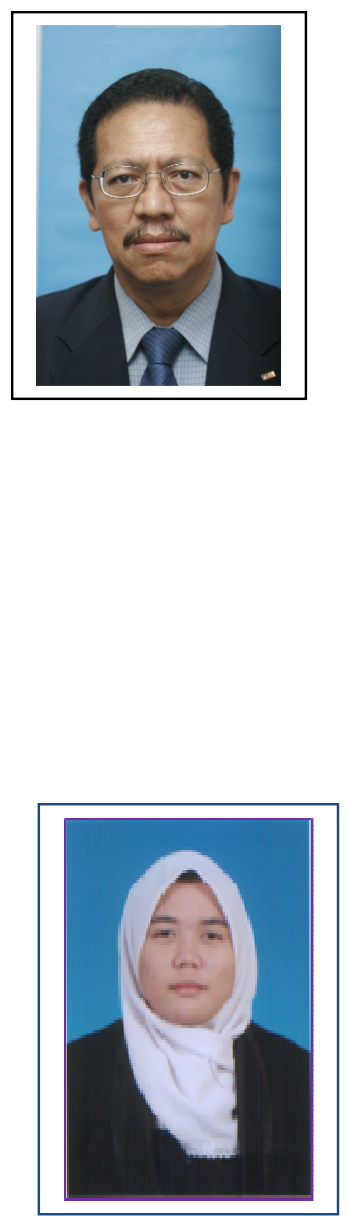